\title{
HANNAH MARIE WORMINGTON
}

\author{
$1914-1994$
}

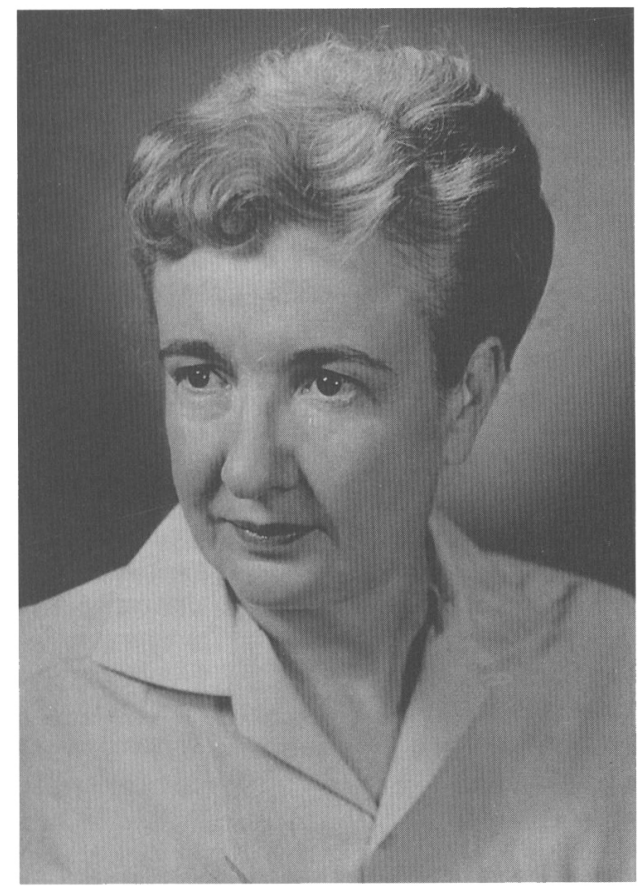

$\mathrm{H}$ annah Marie Wormington, pioneer scholar of Paleoindian archaeology and one of the first female archaeologists in North America, died May 31, 1994, in her native city of Denver. Born on September 5, 1914, she was raised by her mother, Adrienne Roucolle Wormington, a native of France and a noted Denver Post reporter. Marie's early mastery of the French language and an abiding interest in French culture played a major role in her professional development.

While attending East High School in Denver, Marie met John Cotter, who became a lifelong friend and Paleoindian colleague. She later attended the University of Denver, originally intending to study medicine or zoology. Fortunately, in 1932-1933, her sophomore year, she took classes from E. B. Renaud, a French Paleolithic archaeologist and an advocate for Paleolithic cultures in the New World. Those were ground-breaking years for Paleoindian archaeology and much of the early fieldwork was being conducted in New Mexico and Colorado. The discovery of fluted projectile points at the Folsom type site had been recently accepted as evidence of American Ice Age hunters and both the Dent and Blackwater Draw Clovis sites were investigated that year. Meanwhile, Renaud was studying artifacts from the Lindenmeier Folsom site, as well as commencing a survey for early sites in northeastern Colorado. His enthusiasm for the subject was contagious, launching Wormington along a career path that would lead her to become the "Dean of Paleoindian Archaeology." 
When Wormington graduated in 1935, Renaud urged her to travel to Europe to study the Paleolithic. Undaunted by cancellation of her sponsor program at the last minute, Marie, along with her mother, proceeded to France, England, and Spain. In London she met British archaeologist Dorothy Garrod, whom Marie considered her role model. In France she studied typology at the Musée de l'Homme and Laboratoire d'Anthropologie in Paris. That summer she was invited by Henri Martin to participate on his excavations. So it was that Marie spent her 21 st birthday excavating a Paleolithic site in the Dordogne. While working with Martin, she met American Paleoindian archaeologist E. B. Howard, one of the excavators of the Blackwater Draw Clovis site. Marie and her mother traveled with Howard, visiting archaeological sites throughout Spain.

Upon returning to North America, she was hired as staff archaeologist at the Colorado (now Denver) Museum of Natural History, where under the leadership of J. D. Figgins, the museum was preeminent in Paleoindian studies. One of Wormington's first assignments was to catalog the museum's Paleoindian collection, consisting of specimens from all but one (Blackwater Draw) of the excavated Paleoindian sites of the time. Using her typological study of this material, Marie presented her first professional paper at the 1937. International Symposium on Early Man in Philadelphia. An important meeting for Paleoindian studies, it resulted in the first international debate on the subject, and methodologies for projectile point classifications were discussed in detail. The meeting was equally important for Marie professionally, as she presented a well-received paper on Paleoindian flaking techniques, suggesting that typology could be defined on the basis of reduction technology. This paper established her, even at her young age, as a major player in Paleoindian studies, set the course for her future research, and provided the foundation for her first monograph.

She published her first edition of Ancient Man in North America in 1939. This small monograph was the first summary of Pleistocene and early Holocene human occupations of North America. Over the years, Wormington became a central hub in the flow of information regarding Paleoindian research. Three revisions of her book were published, each significantly larger in content as new data were recovered at an ever-quickening rate. The fourth edition, published in 1957, is recognized as a classic in the field of Paleoindian studies and provided an entire generation of avocational and professional archaeologists with their first synthesis of the subject.

During her 31 years with the museum Marie focused her fieldwork in the southwestern United States. In 1936 she tested a Folsom site near La Porte, Colorado, and the following two years turned her attention to the little-known region of the Western Slope of the Rocky Mountains in Colorado and Utah. Her investigations in this area culminated in a definitive monograph on the reappraisal of the Fremont culture, which she published with Robert Lister, as well as an overview guide to the prehistoric Indians of the Southwest, which was widely used as a textbook.

Although it was common for curators of her generation not to have advanced degrees, and in spite of her growing prominence in the profession, Wormington wished to further her formal education. Consequently, she took leave from the museum and began graduate studies at Radcliffe College in the fall of 1937, becoming the school's first Ph.D. candidate in anthropology. During this time she also attended classes at Harvard University, and was the second woman to be admitted to study in Harvard's Department of Anthropology. In the years ahead Marie was to juggle a full-time job, fieldwork, volunteer duties with the Red Cross during World War II, graduate work on the East Coast, and a courtship and marriage to Pete Volk. With persistence she received her M.A. in 1950 and her Ph.D. in 1954.

After 1954 her research focused exclusively on Paleoindian problems, specifically on the search for the origins and antiquity of New World Native Americans. At this time it was thought that the makers of Clovis points were the first Americans, and that they traveled through an ice-free corridor separating the Laurentian and Cordilleran glaciers while on their journey from Siberia to the Western Hemisphere. To test this hypothesis, Wormington, assisted by William Mulloy, conducted a wide-ranging survey of Paleoindian sites in Alberta, the southern end of the corridor. Although they did not verify the hypothesis, Marie coauthored a monograph on Alberta archaeology with Richard Forbis. 


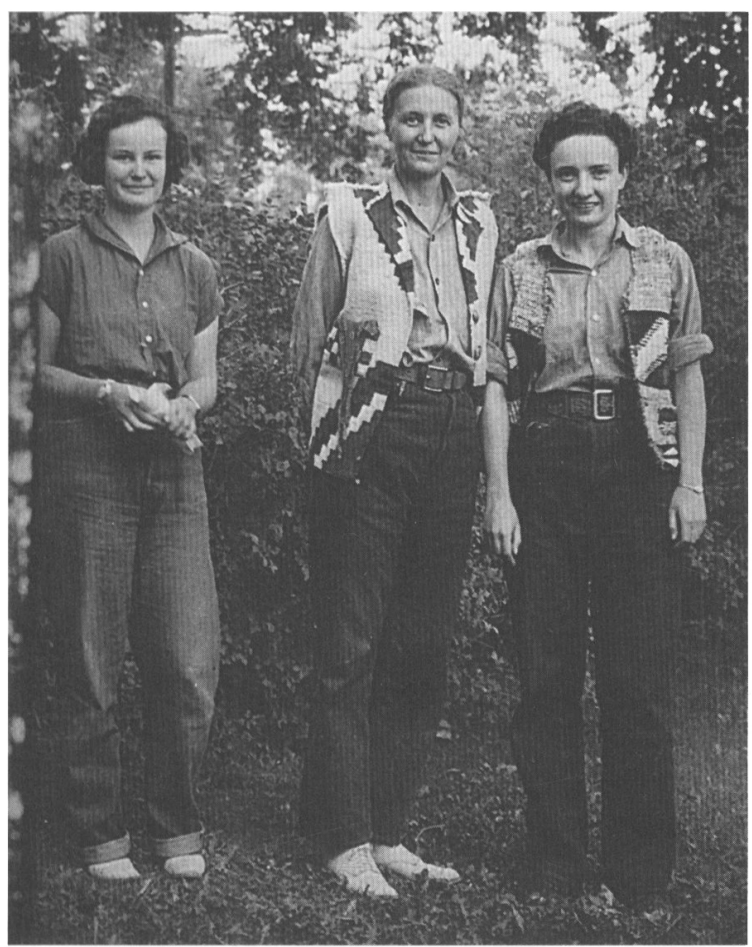

H. Marie Wormington (right), with field assistant Helen (Elliott) Grodotzke (center) and crew member Barbara Morrell (left) at the Turner-Look site, Utah, in 1939.

As the leading expert on the peopling of the Western Hemisphere, she was one of the first American anthropologists to be invited to the Union of Soviet Socialist Republics. As part of a 1958 U.S.-Soviet scientist exchange, Marie spent two months visiting sites and collections in the U.S.S.R. She returned again to study collections in 1961 and 1964. She did not find evidence for Clovis or even a lithic technology from which Clovis could have been derived in the Siberian archaeological data. These studies, along with the pre-Clovis age localities that Cynthia Irwin, her protégé, excavated at Valsequillo, Mexico, caused Marie to rethink the "Clovis First" hypothesis. Although, she was cautious in print, she firmly believed that the Clovis people were not the earliest Americans.

Wormington's final field project, in the mid-1960s, was the excavation of the Frazier site, located near Greeley, Colorado. This site, dating to more than 9,500 years B.P., was an Agate Basin butchering and processing locality. Many of today's Plains Paleoindian specialists cut their teeth while working for Marie at Frazier.

Marie left the Denver Natural History Museum in 1968, the year she was elected as the first female president of the Society for American Archaeology. She also served two terms as vice president in 1950-1951 and 1955-1956 and was the first female archaeologist to receive the society's Distinguished Service Award in 1983. After leaving the museum, she taught at Arizona State University (1968-1969), Colorado College (1969-1970), the University of Minnesota (1973), and was adjunct professor at Colorado College from 1972 to 1986. She was awarded honorary doctor of humane letters degrees from Colorado State University in 1977 and Colorado College in 1988. She was appointed curator emeritus of the Denver Museum of Natural History in 1988.

Throughout her busy career Marie always welcomed eager students of archaeology, be they avoca- 


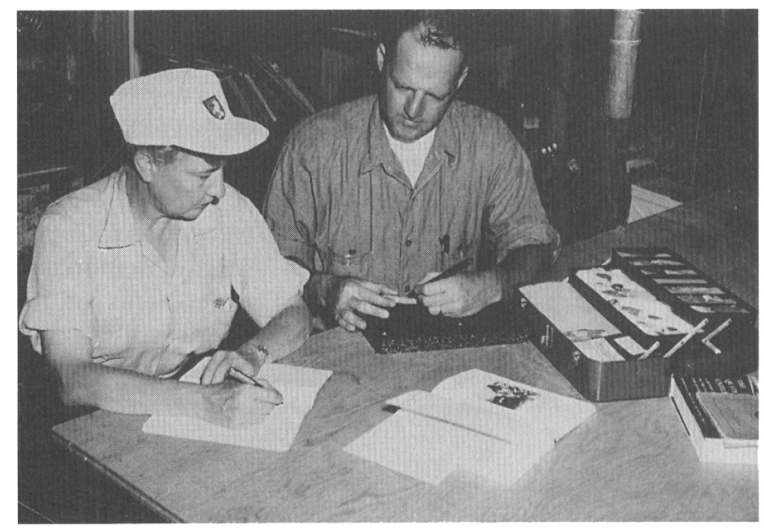

Wormington with field assistant David Acton at the Frazier site, Colorado, in 1966.

tional or professional. She understood the important contributions made to the study of archaeology by nonprofessionals, and she actively promoted cooperation between professional and avocational archaeologists. Many of Marie's publications provided not only important information, but also interesting and readable texts for the general public. She enthusiastically supported local archaeological societies and frequently attended and gave lectures at their meetings. Her efforts on their behalf were recognized by numerous awards, including the C. T. Hurst Award from the Colorado Archaeological Society.

Several of these young student/avocational archaeologists went on to professional careers in Paleoindian research as a direct result of her influence, including C. Vance Haynes, Henry and Cynthia Irwin, and myself. I first met Marie as a freshman in high school, when I brought artifacts collected near my home in Wyoming to the Denver museum to be identified. She generously interrupted her busy schedule to classify my stone tools and encourage my systematic efforts to identify archaeological sites. Whenever I could get to Denver, I would visit her and discuss my latest finds. She introduced me to many anthropologists and encouraged me throughout college and graduate school. After I became a curator at the Smithsonian Institution, and began conducting research in Colorado, her home was often a focal point during the field season. Her pattern of professional and personal generosity was repeated over the years with a great many archaeologists who fondly remember both the archaeological discussions as well as the enjoyable social occasions shared with Marie and her husband Pete. Their home was a natural gathering spot where people and ideas gravitated.

Marie Wormington was a woman of remarkable grace and style. She was a role model to men and women alike, but given the very few women in archaeology at the time, or Paleoindian studies to this day, she was a particularly important pioneer and was an active supporter throughout her career of women in archaeology. We will all miss her very much.

DENNIS STANFORD

\section{Bibliography of Hannah Marie Wormington}

1936 The Case of the Mysterious Folsom. Minnesota Archaeologist 2(6): 16 .

1937 The Amateur Archaeologist. Minnesota Archaeologist 3:41.

1939 American Archaeology: Its Debts to Geology and Other Sciences. The Mines Magazine 29(4):159-161.

Ancient Man in North America. Popular Series
No. 4. Denver Museum of Natural History, Denver. (Fully rev. 4th ed., 1957)

1946 Obituary of Jesse Dade Figgens 1867-1944. American Anthropologist 48:57-77.

1947 Prehistoric Indians of the Southwest. Popular Series No. 7. Denver Museum of Natural History, Denver.

1948 A Proposed Revision of Yuma Point Terminology. Proceedings of the Colorado Museum of Natural History 18(2):1-19. 
1949 A Proposal for Distributional Studies of Fluted and Parallel Flaked Points in North America. Plains Archaeological Conference Newsletter 2(2):20-21.

A Proposed Revision of Yuma Point Terminology. Southwestern Lore 15:26-40.

1950 The Need for Changes in Terminology Used in Studies of Early Stone Industries. In Proceedings of the Sixth Plains Anthropological Conference, 1948, edited by J. D. Jennings, pp. 26-31. Anthropological Papers No. 11. University of Utah, Salt Lake City.

1951 The Story of Pueblo Pottery (with A. Neal). Museum Pictorial No. 2. Museum of Natural History, Denver.

1952 The Present Status of Studies Pertaining to Early $\mathrm{Man}$ in the New World. In International Congress of Anthropological and Ethnological Sciences:311-315. 4th Actas Wien, tome 2. Vienna

1953 Archaeology of the Upper Colorado Plateau Area in the Northern Periphery of the Southwestern United States. Unpublished Ph.D. dissertation, Department of Anthropology, Radcliffe College, Cambridge, Massachusetts.

Origins. Programa de Historia de América, I Periódo Indígena No. 1. Publication 153. Instituto Panamericano de Geograpfia e Historia, Mexico City.

Der Urgeschichtliche Mensch in Nordamerika und die Leitformen seiner Kulturen. Quartar 6 (Halbband) 1:1-18.

1955 A Reappraisal of the Archaeology of the Northern Periphery of the Southwestern United States. Anais do 31, pp. 649-656. Congresso Internacional de Americanistas, Sao Paulo, Brazil.

Reappraisal of the Fremont Culture with a Summary of the Archaeology of the Northern Periphery. Proceedings No. 1. Denver Museum of Natural History, Denver.

1956 Archaeological Investigations of the Uncompahgre Plateau in West Central Colorado (with R. H. Lister). Proceedings No. 2. Denver Museum of Natural History, Denver.

1959 The Amateur Archaeologists. Southwestern Lore 15:11-3.

1960 Comments on the Use of the Term "Yuma." Iowa Archaeological Society Newsletter 8:4-6.

1961 Prehistoric Culture Stages of Alberta, Canada. In Homenaje a Pablo Martínez del Río, pp. 163-171. Mexico City.

1962 An Investigation of Possible Connections Between the Early Metal Using Cultures of
Siberia and the Old Copper Culture. Wisconsin Archaeologist 43(1):20-24.

A Survey of Early American Prehistory. American Scientist 50(1):230-242.

1964 Problems Relating to Paleolithic Techniques in the New World. In Proceedings 35th International Congress of Americanists 1:9-10. Actas y Memorias 1. Mexico City.

The Problems of the Presence and Dating in America of Flaking Techniques Similar to the Paleolithic in the Old World. In Atti del VI Congresso Internazionale delle Scienze Prehistoriche e Protohistoriche 1:273-283. Relazioni Generali, Roma.

1965 An Introduction to the Archaeology of Alberta, Canada (with R. Forbis). Proceedings No. 11. Denver Museum of Natural History, Denver.

1967 The Paleo-indian. In Philadelphia Anthropological Society, Papers Presented on Its Golden Anniversary, edited by J. W. Gruber, pp. 55-66. Columbia University Press, New York.

Pleistocene Studies in Southern Nevada (edited with D. Ellis). Anthropological Papers No. 13. Nevada State Museum, Carson City.

1968 When Did Man Come to North America? In Ancient Hunters of the Far West, edited by R. F. Pourade, pp. 111-124. Copley Press, San Diego.

1970 Paleo-Indian Tool Types in the Great Plains (with H. T. Irwin). American Antiquity 35:24-34.

1971 Comments on Early Man in North America, 1960-1970. Arctic Anthropology 8(2):83-91.

1977 Archaeology of the Late and Post Pleistocene from a New World Perspective. In Paleoanthropology in the People's Republic of China, edited by W. W. Howells, pp. 191-195. National Academy of Sciences, New York.

1979 Obituary of William Thomas Mulloy 1917-1978. American Antiquity 44:513-516.

1981 Introduction. In Breakthrough: Women in Archaeology, by B. Williams, pp. v-vii. Walker, New York.

1983 Early Man in the New World: 1970-1980. In Early Man in the New World, edited by $\mathrm{R}$. Shutler, Jr., pp. 191-195. Sage Publications, Berkeley, California.

1988 The Frazier Site, Colorado. In Guidebook to the Archaeological Geology of the Colorado Piedmont and High Plains of Southeastern Wyoming, edited by V. T. Holliday, pp. 82-84. Department of Geography, University of Wisconsin, Madison.

1994 Obituary of Cynthia Irwin-Williams 1936-1990 (with G. Agogino). American Antiquity 59:667-671. 